This item was submitted to Loughborough's Research Repository by the author.

Items in Figshare are protected by copyright, with all rights reserved, unless otherwise indicated.

\title{
Attaining improved resilience to floods: a proactive multi-stakeholder approach
}

PLEASE CITE THE PUBLISHED VERSION

http://dx.doi.org/10.1108/09653560910938501

PUBLISHER

(C) Emerald Group Publishing Limited

VERSION

AM (Accepted Manuscript)

LICENCE

CC BY-NC-ND 4.0

\section{REPOSITORY RECORD}

Bosher, Lee S., Andrew R.J. Dainty, Patricia M. Carrillo, Jacqueline Glass, and Andrew D.F. Price. 2019. "Attaining Improved Resilience to Floods: A Proactive Multi-stakeholder Approach". figshare. https://hdl.handle.net/2134/4241. 
This item was submitted to Loughborough's Institutional Repository (https://dspace.lboro.ac.uk/) by the author and is made available under the following Creative Commons Licence conditions.

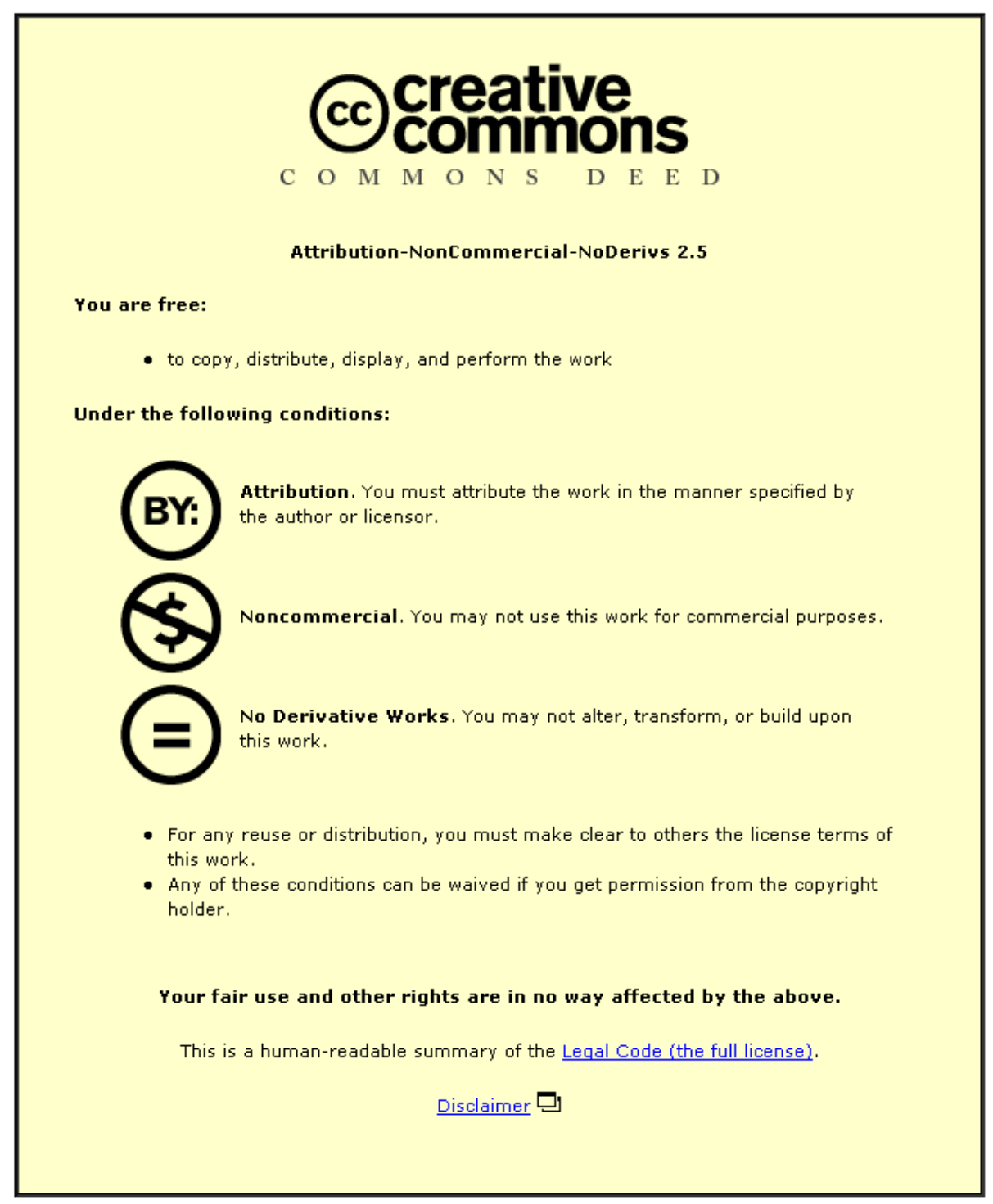

For the full text of this licence, please go to: http://creativecommons.org/licenses/by-nc-nd/2.5/ 


\title{
Attaining improved resilience to floods: A proactive
}

\section{multi-stakeholder approach}

\author{
Lee Bosher (corresponding author) \\ Andrew Dainty \\ Patricia Carrillo \\ Jacqueline Glass \\ Andrew Price
}

\author{
Address for Correspondence \\ Dr Lee Bosher, \\ Department of Civil and Building Engineering, \\ Loughborough University, \\ Leicestershire, England, LE11 3TU E-mail: 1.bosher@lboro.ac.uk
}

\section{Biographies:}

Lee Bosher is a Research Fellow.

Andrew Dainty is a Professor of Construction Sociology.

Patricia Carrillo is a Professor of Strategic Management in Construction.

Jacqueline Glass is a Lecturer in Architectural Engineering.

Andrew Price is a Professor of Project Management

All the authors are based in the Department of Civil and Building Engineering at Loughborough University, England.

Word count: 5,115 


\title{
Attaining improved resilience to floods: A proactive multi-stakeholder
}

\section{approach}

\author{
Lee Bosher, Andy Dainty, Patricia Carrillo, Jacqueline Glass and Andrew Price \\ Department of Civil and Building Engineering, Loughborough University, Loughborough, England \\ LE11 3TU, UK. Email: L.Bosher@Lboro.ac.uk
}

\begin{abstract}
Purpose: There is a need to pro-actively address strategic weaknesses in protecting the built environment from a range of hazards. This paper is focused on the mitigation for flood hazards in the UK; particularly in understanding the extent of the problem, collating key guidance and legislation related to flood hazard mitigation, identifying who the key construction decision makers are and the most opportune stages of the Design-Construction-Operation Process when they need to make their key decisions.
\end{abstract}

Design/methodology/approach: A pluralistic research design was adopted for the study, which included a UK-wide questionnaire survey and a set of semi-structured interviews involving a range of professionals from construction, planning, insurance, emergency management and local/national government agencies was undertaken.

Findings: Despite the publication of a range of guidance on flood hazard mitigation in the UK there is still insufficient evidence that key construction stakeholders are playing an active role in mitigating flood risk. The pre-construction phase of a building's life cycle is identified as is the most critical stage when key stakeholders need to adopt flood hazard mitigation strategies. The socio-institutional constraints to the proactive attainment of built-in resilience are highlighted as are recommendations as to how these constraints can be addressed.

Research limitations/implications: This paper reports on the provisional findings of an ongoing project but these findings nonetheless provide essential foundations for the latter development of the PRE-EMPT toolkit and also raise some important considerations about flood resilience in the UK.

Originality/value: The findings presented reveal how stakeholders should be better involved, and what issues they need to address, regarding the integration of built-in resilience into construction decision making.

Keywords: decision-making, flood hazard, resilience, mitigation UK.

Paper type: Research Paper 


\section{Introduction}

“The floods during June and July 2007 were a wake-up call. The three months from May to July were the wettest since records began and the events that followed have been linked to the deaths of 13 people. They also resulted in damage to approximately 48,000 homes and 7,000 businesses. Power and water supplies were lost, railway lines, eight motorways and many other roads were closed and large parts of five counties and four cities were brought to a standstill.”

(Cabinet Office 2007:3).

Threats to society and the built environment, are diverse and include extreme natural hazards (such as windstorms and floods) and human induced hazards (such as terrorist attacks). The 'Stern Review' (Cabinet Office/H.M. Treasury, 2006) warns of a bleak future for the planet if societies and the built environment do not adapt to address the implications of a changing climate and the report goes as far as stating that the benefits of strong and early action far outweigh the economic costs of not acting.

Typically, natural and human induced hazards cause minor disruption to the economy, infrastructure and residents of the United Kingdom (UK) but it has been argued that the magnitude and frequency of these extreme events are increasing due to the implications of climate change (Cabinet Office/HM Treasury 2006) with the result that the nation's built environment is likely to become increasingly vulnerable. Ofori (2008) states that the immutable nature of built assets, the inability to accurately test them for resilience, the legislative and socio-economic requirements of development, requirements for ongoing maintenance, adaptation and redevelopment, and potential appropriation by the end user all render built assets vulnerable to a wide range of hazards which will change over time. It would also appear that with socio-economic progress, society becomes 
more vulnerable as urban areas become reliant on their increasingly extended supply lines (Menoni 2001), and ever-expanding and vital distribution networks of water, power, gas and telecommunication systems. Moreover, with globalisation, major urban settlements are also interconnected; an extreme event in one of them can precipitate widespread disruption in many others.

Given this backdrop, this paper will discuss why it is important to embed flood hazard mitigation into pre-construction decision making. However, for this to occur, a wide range of stakeholders (such as engineers, designers, and urban planners) need to be consulted and actively involved in more informed decision-making.

\section{Towards a more proactive approach to resilience}

The observed shift in the way disasters are being managed has been illustrated by the move away from the reactive attributes of Disaster Management towards the more proactive Disaster Risk Management (DRM) paradigm that should be 'mainstreamed' into developmental initiatives (DFID 2006). The United Nations’ International Strategy for Disaster Reduction (UN/ISDR 2004) has adopted a concept of DRM that can be summarised into four mutually interconnected phases (Figure 1), being: 1) Hazard identification, 2) Mitigative adaptations, 3) Preparedness planning; and, 4) Recovery (short-term) and reconstruction (longer-term) planning.

\section{[Take in Figure 1]}

DRM should be concerned with people’s capacity to: manage their natural, social and built environments; and take advantage of it in a manner that safeguards their future and that of forthcoming generations. DRM needs to be holistic; it must ensure that associated strategies are viewed as a shared responsibility towards the attainment of resilience that includes issues such as 
hazard mitigation (Pelling 2003; Trim 2004) and land-use planning (Burby et al. 2000; Wamsler 2004). Part of the shared responsibility that is required could be achieved by embedding construction professionals, who possess the knowledge and experience of how to design, build, retrofit and operate what are typically bespoke built assets, into the DRM framework (Bosher et al. 2007b). The construction sector should play an important role in the structural ${ }^{1}$ elements of mitigation (and adaptation), while developers and planners should be able to positively influence the non-structural ${ }^{2}$ elements (Wamsler 2006). However, there is little evidence of DRM being a priority for construction professionals, which may explain the apparent inability of the industry to mitigate the effects of natural and human-induced threats (Bosher et al. 2007a). Thus, integrating the multitude of disciplines responsible for how the built environment is delivered is critical to the mainstreaming of DRM into long-term development (Dainty and Bosher 2008).

\section{The importance of resilience}

In recent years the concept of 'resilience', the capacity of human and physical systems to cope with and respond to extreme events, has become an increasingly prominent issue that complements the 'sustainability' agenda. Indeed the concept has largely supplanted the concept of 'resistance' with its focus on pre-disaster mitigation (Tierney and Bruneau 2007). This may reflect the realisation that the changing nature of natural and human-induced threats are such that a nation's built environment can never really be future-proofed to be totally resistant (Dainty and Bosher, 2008).

The contemporary focus therefore, has shifted to ensuring the capability of the built environment to both resist and recover rapidly following extreme (but arguably more regularly occurring) events. Despite the theoretical attractiveness of this proposition however, the structure of the construction industry and the nature of the interaction between those who plan, design, construct, operate and maintain the built environment provides a problematic context within which resiliency considerations can be integrated. The socio-political landscape of the industry and professions 
arguably act as fundamental impediments to the achievability of this goal (ibid.). Attaining more resilient infrastructure will therefore demand a paradigm shift in the way that built environment professionals integrate their activities and interact with the communities within which built assets reside. It is also important to appreciate that resilience is a multi-faceted concept which includes physical, social, economic and institutional components; the socio-institutional aspects are arguably as important to the attainment of resilience as the physical aspects because 'resilient engineering' also demands a more resilient infrastructural context with regards to the professions, the structures and processes which govern construction activity. As Godschalk (2003: 42) notes, 'if we are to take the achievement of urban resilience seriously, we need to build the goal of the resilient city into the everyday practice of city planners, engineers, architects, emergency managers, developers and other urban professionals. This will require a long-term collaborative effort to increase knowledge and awareness about resilient city planning and design'.

Such knowledge is likely to come from several areas of inquiry all of which will form a new synthesis for achieving more resilient built environments. Bosher et al. (2007a) point to a number of key actions required to address systems in the built environment that are at risk from natural and human induced hazards. These actions are categorised as broadly relating to: Innovation and knowledge (new technologies, trans-disciplinary training and hazard awareness); Operations (information exchanges between a wide range of stakeholders such as planners, designers, engineers and the emergency services); Planning (well designed and suitable locations), and; Legislation and regulatory incentives (building codes and good practice guidance) (Ibid.). However, at present in many countries developing resilience against natural and human induced threats is an agenda which has been developed almost exclusively by politicians and emergency planning professionals with little if any discussion with citizens, the business community, town planners, urban designers and other built environment professionals (Coaffee 2008). Little (2004: 55) acknowledges that a fully inclusive strategy for urban resilience is required because it 'will be neither holistic nor effective if it 
is restricted to narrow professional or disciplinary stovepipes or if interactions among government officials, security professionals, program and financial staff, and emergency responders occurs only on a product by product basis'.

\section{Riverine flooding hazards}

Approximately 10,000 $\mathrm{km}^{2}$ (or 8 percent of the total area) of land in England is at risk from fluvial (river) flooding, including tidal rivers and estuaries (DTLR 2001). An estimated five million people, two million homes and 185,000 businesses are at risk from flooding in England and Wales every year, with total exposed property, land and assets amounting to £214bn (Crichton 2005). The risk of flooding in the UK can be increased to a certain extent due to changes in river hydrology caused by human activity and partly from the increase of development in areas at risk. It is expected that climate change will increase the risk of coastal and river flooding as a result of sea-level rise and more intense rainfall events. The 'Foresight Report' (Office of Science and Technology 2004) suggested that annual average damages could increase from $£ 1$ bn to between $£ 2$ bn and $£ 21 \mathrm{bn}$ if no action is taken to manage the increased risk. These figures are particularly germane as housebuilding rates are anticipated to increase to the level recommended in the Barker report (Barker 2004) that has suggested that over the next 10 years almost 200,000 homes would be built each year on previously developed land. Development to this level would require over 70,000 hectares of land that was previously used for industrial or residential purposes, much of which will be located in the floodplain (DEFRA 2004). This is a particular concern because there are already 'over 2,000 schools and 80 hospitals in flood hazard areas in England' (Crichton 2008: 125).

It should also be noted that pluvial flooding (typically associated with abundant rainfall in a localised area, and exacerbated by insufficient capacity of urban drainage systems) has also increased in prominence on the flood risk agenda in light of the Summer 2007 floods. For instance the flooding that inundated the coastal city of Hull affected 8,600 homes and 1,300 businesses and 
has now largely been attributed to the city’s drainage network being totally overwhelmed by heavy and prolonged rain (Coulthard et al. 2007). The implications of the flooding that was experienced in Hull on hazard mitigation strategies will be discussed later in this paper.

\section{The Research}

There is a need to pro-actively address strategic weaknesses in protecting the built environment from a range of hazards. This component of the research is focused on the mitigation for flood hazards in the UK; particularly understanding the extent of the problem, collating key guidance and legislation related to flood hazard mitigation, identifying who the key construction decision makers are and the most opportune stages of the Design-Construction-Operation Process when they need to make their key decisions. Through this, the paper will also highlight some of the socio-institutional constraints to the proactive attainment of built-in resilience and provide some suggestions as to the approaches that may be required to address these constraints.

\section{Methods}

A pluralistic research design was adopted for the study using a complementary range of datasets and research methods. A state of the art literature review; including academic papers, governmental and non-governmental reports, UK legislation and regulations, governmental, institutional and industrial guidelines and policy documentation was undertaken to identify key guidance, standards and legislation related to flood hazard mitigation in the UK. The EM-DAT database (EM-DAT 2007) of global emergency events was searched and analysed to assess the most prevalent and high impact (regarding financial costs and the loss of human life) disasters in the UK. Between July and November 2007, 50 questionnaire surveys were also completed by a selective range of experts involved with construction, risk and emergency management, local and national government and urban planning. These questionnaires were designed to elicit perspectives and opinions about hazard and threat awareness and knowledge of available governmental and non-governmental 
guidance for hazard mitigation and emergency preparedness. This data was augmented by eleven semi-structured in-depth interviews with experts from the construction sector, engineering, emergency planning, and urban planning.

\section{Preliminary research findings}

The findings raise some important issues about the construction sector's role in hazard mitigation, with a specific focus on the mitigation of riverine flood hazards. The datasets have been combined below in relation to the type of threats apparent, the efficacy of current guidelines and the role and input of various stakeholders.

\section{Evaluation and prioritisation of identified threats}

An analysis of the data ${ }^{3}$ obtained from the EM-DAT database (EM-DAT 2007) of global emergency events indicates that, from an historical perspective, the greatest threats to the built environment in the UK are from flooding (riverine, pluvial and coastal) and severe windstorms. The perspectives and opinions of key threats to the built environment were sought from the respondents and these were found to be very much in-line with the historical data with pluvial and riverine flooding considered as the key threats (Table 1).

\section{[Take in Table 1]}

The respondents' awareness of the threat from flooding events (riverine, pluvial and coastal) was high and supports the findings from previous research (see Bosher et al. 2007c) that found the majority of over 100 respondents from the construction sector in the UK perceived flood risk to be the most prominent threat to the built environment. A particularly interesting observation from the questionnaires was that according to the respondents, none of the threats associated with the key identified hazards have been significantly reduced in the last decade (Table 2). This observation is 
somewhat unexpected because it is in spite of numerous efforts (by government and business) to address such hazards; through for instance, flood defences, Sustainable Urban Drainage Systems, increased spending and resources on intelligence to counter terrorism and rafts of legislation and guidance to improve the safety of industrial sites. One of the interviewees posited a suggestion as to why the apparent increase in the scale of the threats might be occurring:

“Many people I work with feel that the UK has sat on it's laurels for far too long now and that the flooding and windstorm damages experienced in the last couple of years are merely the sour fruits of the government's and the construction sector's short-termism and procrastination. We are doing too little too late to proactively mitigate for an ever increasing range threats”.

(Interview with National Security consultant)

\section{[Take in Table 2]}

\section{Current guidelines}

This study has found that while there is an ever increasing range of guidance, information and legislation, there is a lack of suitable guidance that is specifically focused on proactive flood mitigation measures that are targeted for use by key stakeholders in the construction sector. When suitable guidance is available, awareness of when and how to best use it is poor. Table 3 provides a non-exhaustive list of key guidance, standards and policy related to riverine flooding in the UK; the few documents that were used by a majority of the respondents are shown in italics. The findings of earlier research (see Bosher et al. 2007b) also revealed that the lack of coherent guidance on how hazard mitigation considerations should be integrated into the Design-Construction-Operation Process is likely to inhibit the ability of the construction industry to proactively design and build a more resilient built environment and also constrain appropriate re-construction (and resilient reinstatement) of flood affected properties. 


\section{[Take in Table 3]}

The flooding events in the UK in 2007 (and 2005) have underscored the importance of achieving a more informed and joined up multi-stakeholder approach to attaining a resilient built environment. The recent publication of the 'Improving the Flood Performance of New Buildings' ${ }^{4}$ document by the Department of Communities and Local Government is a move in the right direction as it is targeted at the developers and designers that are 'keystones' in the 'built-in resilience' agenda espoused in this paper.

"From a business point of view we need to ensure that we do not 'scare off' the developer or client by saying we will be considering hazard mitigation issues. Nine times out of ten the developer or client will assume these 'resilience' measures will cost them more money; so they may ditch us and go for the contractor that they perceive as being better value for money, or in other words is the 'cheapest' option. The developers and clients are the 'keystones' to the attainment of built-in resilience. I am confident that this construction company has the skills and knowledge required to attain built-in resilience, we just need stakeholders such as the developers and clients to start looking past short-term profits."

(Interview with Technical Manager - Large construction company)

This comment suggests that developers and clients may be central to either helping or hindering the 'resilience' agenda. However, while it is pertinent to acknowledge that these are indeed key stakeholders, it is also important to appreciate that there is a wider range of stakeholders that need to be engaged with the resilience agenda; therefore a range of strategies will need to be utilised. For instance, the pluvial flooding that occurred in Hull illustrates an important aspect of hazard mitigation; Who is to blame? Or rather, who is in charge? Many organisations are responsible for 
different parts of drainage systems and other water courses in the UK and this makes overall management extremely difficult. This is a problem that was highlighted by the Independent Review Body of the floods which stated, "In short no single agency accepts responsibility for any elements outside their terms of reference. This is a recurring theme - one of inadequate consultation, cooperation and unity between the agencies. These practices must end.” (Coulthard et al. 2007: 34). The experiences of Summer 2007 demonstrate that a more coordinated approach to dealing with not only the consequences of floods but also the mitigation of flood hazards needs to be high on the Government's agenda.

\section{Identification of key stakeholders}

A review by Sir Michael Pitt into the 2007 summer floods in the UK concluded, amongst numerous other issues, that a lack of clarity in the responsibilities of government agencies and nongovernmental stakeholders was one of the key factors that contributed towards the extent of the flooding (Cabinet Office 2007). Appropriately informed stakeholder decision-making is therefore an important aspect of how disastrous events can be reduced and managed. Previous research has demonstrated which stakeholders should be involved in DRM activities and also at what stages of the Design-Construction-Operation Process (DCOP) these stakeholders should be involved (for details see Bosher et al. 2007b). The pre-construction phase was identified as the critical phase in the DCOP when DRM activities, and specifically hazard mitigation, can be (and need to be) integrated. It is during this phase in particular that hazard mitigation considerations should be made by architects/designers, structural and civil engineers, urban planners, specialist contractors and emergency/risk managers (Table 4). 


\section{[Take in Table 4]}

\section{Discussion}

This research has so far revealed that while there is an ever increasing range of guidance, information and legislation for stakeholders in the construction sector, there is a lack of suitable guidance that is specifically focused on proactive mitigation measures that are targeted for use by key stakeholders in the construction sector. When suitable guidance is available, awareness of such guidance by key construction related decision makers is poor. It is also important to not only know about the guidance but it is also essential that the key decision-makers are aware that the preconstruction phase is the critical stage of the Design-Construction-Operation process when flood hazard mitigation should be undertaken by architects/designers, structural and civil engineers, urban planners, specialist contractors and emergency/risk managers.

Reaching out to this wide array of stakeholders and integrating their inputs suggests that a complementary range of strategies will be required to address the issue of building-in flood resilience (as well as resilience to other hazards) into the decision-making of construction stakeholders. It is likely that these strategies will include, 'innovation and knowledge', 'operations', 'planning' and 'legislative and regulatory' initiatives that will need to be driven by developers, construction firms, planners and governmental agencies (amongst others).

\section{Innovation and knowledge}

Achieving built-in resilience will demand that traditional demarcations in roles and responsibilities are reconstituted in order to propagate the free-flow of knowledge between the stakeholders (Dainty and Bosher 2008). This strategy should therefore include developing new more resilient technologies and materials and initiating trans-disciplinary training and hazard awareness 
programmes for construction professionals. Threats to the built environment should not be seen as problems but as opportunities to develop and provide niche products and solutions related to hazard mitigation.

\section{Operations}

Professional fragmentation is a hallmark of the construction industry, with architects, surveyors and engineers usually employed from outside construction firms as independent consultants (Morton 2002). Therefore, the difficulties of trying to facilitate this information exchange in an environment with fragmented relationships between the various actors renders this a problematic notion (see Trim 2004; Lorch 2005). Facilitating information exchanges between stakeholders such as planners, designers, engineers and the emergency services will be an important requirement (possibly one that could be achieved by encouraging the invovlement of construction stakeholders in Local and Regional Resilience Forums).

\section{Planning}

The publication of 'Planning Policy Statement 25: Development and Flood Risk' (PPS25) by the UK Government has helped to incorporate flood risk into the planning process. However, PPS25 (DCLG 2006) has been criticised because it continues to permit development in flood plains if there is nowhere safer to build. Therefore, improved guidance that is targeted at planning and urban design practitioners will need to be developed to support well designed developments that are not located in flood risk areas.

\section{Legislation and regulatory incentives}

At present in many countries developing resilience against natural and human induced threats is an agenda which has been driven almost exclusively by politicians and emergency planning professionals with little, if any, discussion with citizens, the business community, town planners, 
urban designers and other built environment professionals (Coaffee 2008). One of the strategies required to help attain improved resilience to riverine flooding is likely to include the revision of building codes and developing good practice guidance on a number of measures (such as the resilient reinstatement of flood affected buildings, see Soetanto et al. 2008 for details). It is therefore important that built environment professionals are consulted and actively involved in the revisions that will undoubtedly be required to make built assets in the UK more resilient to an ever increasing flood risk.

\section{Engaging with key stakeholders}

Little (2004) acknowledges that a fully inclusive strategy for urban resilience is required. Therefore, one of the key challenges in attaining built-in resilience will be in sufficiently engaging with key stakeholders from the construction sector and increasing their awareness of not only appropriate hazard mitigation approaches, but also the important roles they can play in proactively mainstreaming the principles of 'resilience' into long-term development. A top down approach to achieving stakeholder engagement is likely to be constrained by the aforementioned problems of traditional demarcations in roles and responsibilities and the fragmented relationships between the myriad construction professions; a bottom up and multi-disciplinary approach may be the way forward.

Charrette workshops are a technique used by practitioners to involve various individuals and organisations directly in the planning, programming, or design of a project. The charrette is often used in community planning to encourage involvement from local stakeholders; multi-disciplinary charrettes were used as part of the PRE-EMPT Project to explore the issues of creating resilient buildings. During the charrette, a design scenario was tabled, with supporting documentation; the design actions of the invited group of key stakeholders were the focus for a set of predominantly qualitative research instruments to analyse differences in process, actions, conflicts and resolutions. 
These charrettes ${ }^{5}$ have enabled a review of current decision making processes during project briefings whilst also identifying how decisions have been informed. This process has been a key component in the ongoing development of user defined decision support tools ${ }^{6}$ that will enable stakeholders to integrate 'resilience' options into how they plan, design, build, operate, maintain and reconstruct the built environment. The charrettes have also been an important research tool in not only obtaining rich qualitative data for the research team on decision making processes, but also in aiding the collaborating organisations to understand the strengths and weaknesses in their approaches to hazard mitigation and in stimulating informed decision-making for built-in resilience.

\section{Conclusions}

The pre-construction phase of a building's life cycle is the most critical for incorporating flood hazard mitigation strategies that should be undertaken by stakeholders such as architects/designers, structural and civil engineers, urban planners, specialist contractors and emergency/risk managers. However, despite the publication of a range of guidance on flood hazard mitigation in the UK there is little evidence to suggest that key construction stakeholders are playing an active role in mitigating flood risk. It is argued that the construction sector is currently ill-prepared to build-in resilience to flooding in the UK. Resilience is a multi-facetted concept which includes physical, social, economic and institutional components; the socio-institutional aspects are arguably as important to the attainment of resilience as the physical aspects because 'resilient engineering' also demands a more resilient infrastructural context with regards to the professions, the structures and processes which govern construction activity. This paper has argued that fundamental institutional change and the provision of better guidance and training are required if the 'innovation and knowledge', 'operations', 'planning' and 'legislative and regulatory' initiatives towards built-in resilience are to be successful. These underlying institutional conditions will be difficult to obtain in 
a short period of time so other, possibly more discrete, approaches may be required in the meantime.

One of the approaches could include the development of decision-support tools that could be applied during the pre-construction, construction and post-disaster reconstruction phases. The development of a decision support tool could enable construction stakeholders, such as civil and structural engineers and architects, to make informed decisions regarding the proactive integration of flood hazard mitigation (and the mitigation of other hazards) during the design, planning, construction, operation and maintenance of existing and future construction projects.

\section{Acknowledgements}

Funding for this research came from the Engineering and Physical Science Research Council (EPSRC) in the UK, via the Innovative Manufacturing and Construction Research Centre (IMCRC) at Loughborough University. The authors would like to acknowledge the comments and suggestions provided by the anonymous reviewers of this paper. Any remaining errors are the responsibility of the authors.

\section{References}

Barker K., (2004) Review of Housing Supply: Delivering stability: securing our future housing needs, Office of the Deputy Prime Minister, HMSO, London

Bosher L.S., (ed.), (2008), Hazards and the Built Environment: Attaining Built-in Resilience, Routledge, London 
Bosher L.S., Carrillo P.M., Dainty A.R.J., Glass J., and Price A.D.F., (2007a), 'Realising a resilient and sustainable built environment: Towards a strategic agenda for the United Kingdom', Disasters, 31 (3):236-255

Bosher L.S., Dainty A.R.J., Carrillo P.M., and Glass J., (2007b) 'Built-in Resilience to Disasters: A Pre-Emptive approach', Engineering Construction and Architectural Management, 14 (5): 434-446

Bosher L.S., Dainty A.R.J., Carrillo P.M., Glass J., and Price A.D.F., (2007c), 'Integrating disaster risk management into construction: A UK perspective', Building Research and Information, 35 (2):163-177

Burby R., Deyle R.E., Godschalk D.R. and Olshansky R.B., (2000), 'Creating hazards resilient communities through land-use planning’, Natural Hazards Review, 1 (2): 99-106

Cabinet Office, (2007), The interim conclusions of The Pitt Review - Learning Lessons from the 2007 Floods, Cabinet Office, London

Cabinet Office/HM Treasury, (2006), Stern Review on the Economics of Climate Change, Cabinet Office/Her Majesty’s Treasury, London

Coaffee J., (2008), 'Security planning in the resilient city: Stimulating integrated emergency planning and management' in Bosher L.S., (ed.), (2008): pp. 300-316

Coulthard T.J., Frostick L., Hardcastle H., Jones K., Rogers D., Scott M. and Bankoff G. (2007) The 2007 floods in Hull. Final report by the Independent Review Body, 21 ${ }^{\text {st }}$ November 2007, Hull City Council, 68pp.

Crichton D., (2008), 'Role of Insurance in Reducing Flood Risk’, The Geneva Papers 33: 117-132 
Crichton D., (2005), 'About Floods', Working paper, Benfield Hazard Research Centre, UCL, London

Dainty A.R.J. and Bosher L.S., (2008), 'Afterword: Integrating resilience into construction practice’ in: Bosher L.S., (ed.), (2008): pp. 357-372

DCLG, (2006), Planning Policy Statement 25: Development and Flood Risk, London: Department of Communities and Local Government.

DEFRA, (2004), Study into the environmental impacts of increasing the supply of housing in the UK, DEFRA Statistics, April 2004, Department for Environment, Food and Rural Affairs, London

DFID, (2006), Reducing the Risk of Disasters, Department for International Development, East Kilbride

DTLR, (2001), Planning Policy Guidance 25: Development and Flood Risk, December 2001, Department for Transport, Local Government and the Regions, HMSO, London

EM-DAT, (2007), The OFDA/CRED International Disaster Database, Université catholique de Louvain - Brussels - Belgium

Glass J., Dainty A.R.J., Bosher L.S., Carrillo P.M., and Price A.D.F., (2008), 'Stimulating informed decision making for built-in resilience through the use of Charrette workshops’, Proceedings of the Building Abroad Conference: Procurement of construction and reconstruction projects in the international context, $23^{\text {rd }}-25^{\text {th }}$ October, Université de Montréal, Montréal, Canada

Godschalk D., (2003), 'Urban hazard mitigation: creating resilient cities’, Natural Hazards Rev., 4 (3): $136-43$. 
Little R., (2004) 'Holistic strategy for urban security', Journal of Infrastructure Systems, 10 (2): 52-9.

Lorch, R., (2005), What lessons must be learned from the tsunami? Building Research and Information, 33 (3). pp. 209-211

Menoni S., (2001) 'Chains of damages and failures in a metropolitan environment: some observations on the Kobe earthquake in 1995', Journal of Hazardous Materials, 86 (1-3):10119

Morton R, (2002), Construction UK: Introduction to the Industry, Blackwell Publishing, Oxford

Office of Science and Technology, (2004), Foresight Flood and Coastal Defence Project, Office of Science and Technology, London

Ofori G., (2008), 'Construction in developing nations: Towards increased resilience to disasters', in: Bosher L.S., (ed.), (2008): pp.39-60

Pelling M., (2003), The vulnerability of cities: natural disaster and social resilience, Earthscan, London

Soetanto R., Proverbs D., Lamond J. and Samwinga V., (2008), 'Residential properties in England and Wales: An evaluation of repair strategies towards attaining flood resilience' in: Bosher L.S., (ed.), (2008): 124-149

Tierney K. and Bruneau M., (2007), 'Conceptualizing and Measuring Resistance: A Key to Disaster Loss Reduction’. TR News 250, May - June 2007, pp.14-17.

Trim P., (2004), ‘An Integrated Approach to Disaster Management and Planning', Disaster Prevention and Management, 13 (3): 218-225 
UN/ISDR, (2004), Living with Risk: A global review of disaster reduction initiatives, United Nations International Strategy for Disaster Reduction, Geneva

Wamsler C., (2006), 'Mainstreaming risk reduction in urban planning and housing: a challenge for international aid organisations’, Disasters, 30 (2):151-177

Wamsler C., (2004), 'Managing Urban Risk: Perceptions of Housing and Planning as a Tool for Reducing Disaster Risk’, Global Built Environmental Review (GBER). 4 (2): 11-28 


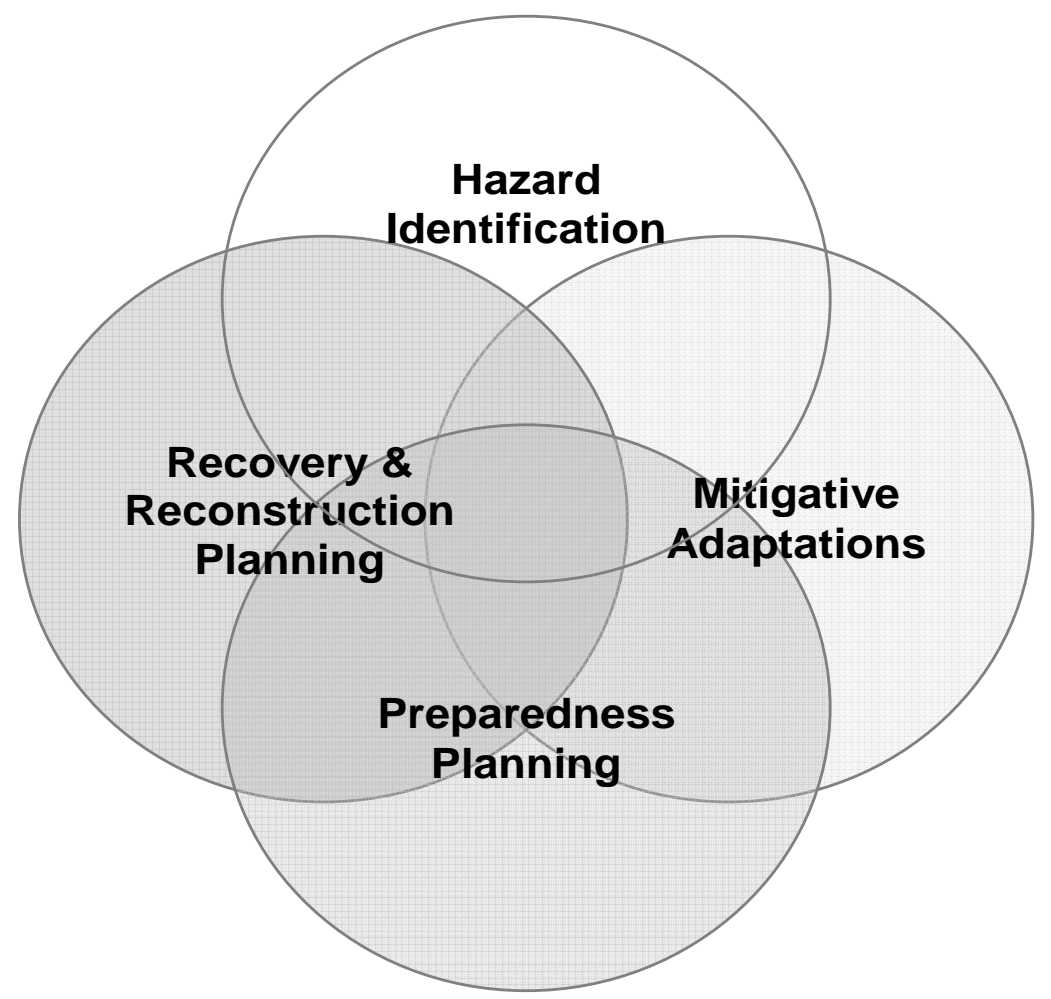

Figure 1: The interconnected phases of the DRM Framework

Table 1: Perceptions of major threats to the built environment in the UK

\begin{tabular}{lccc} 
& \multicolumn{3}{c}{ Responses (\%) } \\
\cline { 2 - 4 } Threats & $\begin{array}{c}\text { Agree/ strongly Neither agree or } \\
\text { agree }\end{array}$ & $\begin{array}{c}\text { Disagree/ } \\
\text { disagree }\end{array}$ & $\begin{array}{c}\text { strongly } \\
\text { disagree }\end{array}$ \\
\hline Coastal flooding & $\mathbf{8 8}$ & 6 & 6 \\
Earthquakes/tremors & 16 & 26 & $\mathbf{5 8}$ \\
Flooding (pluvial) & $\mathbf{9 4}$ & 2 & 4 \\
Heat waves & $\mathbf{6 7}$ & 25 & 8 \\
Industrial explosions & 44 & 34 & 22 \\
Landslides subsidence & $\mathbf{6 6}$ & 24 & 10 \\
Transportation emergencies & 50 & 40 & 10 \\
Riverine flooding & $\mathbf{9 2}$ & 8 & 0 \\
Terrorist bombs & $\mathbf{7 8}$ & 10 & 12 \\
Tornadoes & 22 & 48 & 30 \\
Windstorms & $\mathbf{7 6}$ & 12 & 12 \\
\hline
\end{tabular}


Table 2: Perceptions of whether threats from hazards have increased or decreased in the last decade

Responses (\%)

\begin{tabular}{lcccc}
\cline { 2 - 5 } Threats & Increased & $\begin{array}{c}\text { Neither } \\
\text { increased or } \\
\text { decreased }\end{array}$ & Decreased & Don't know \\
\hline Coastal flooding & $\mathbf{8 0}$ & 18 & 0 & 2 \\
Earthquakes/tremors & 6 & $\mathbf{8 4}$ & 2 & 8 \\
Flooding (pluvial) & $\mathbf{9 2}$ & 4 & 0 & 4 \\
Heat waves & $\mathbf{6 8}$ & 28 & 0 & 4 \\
Industrial explosions & 14 & 56 & 28 & 2 \\
Landslides subsidence & 36 & 52 & 6 & 6 \\
Transport'n emergencies & 44 & 42 & 12 & 2 \\
Riverine flooding & $\mathbf{9 0}$ & 10 & 0 & 0 \\
Terrorist bombs & $\mathbf{9 0}$ & 10 & 0 & 0 \\
Tornadoes & 32 & 50 & 0 & 18 \\
Windstorms & 46 & 50 & 2 & 2 \\
\hline
\end{tabular}

Table 3: Selection of guidance available to construction professionals for addressing riverine flooding in the UK

\section{Details of available guidance for riverine flooding in the UK}

(from Governmental and private sector sources)

Documents that were identified and used by a majority of the respondents are shown in italics

\section{Pre-design and design stages}

- BS EN 752-4:1998 Drain and sewer systems outside buildings. Hydraulic design and environmental considerations

- BS EN 13564: Anti-flooding devices for buildings

- PAS 1188-2:2003 Flood protection products. Specification. Temporary and demountable products

- PAS 1188-1:2003 Flood protection products. Specification. Building apertures

- PAS 64:2005 Professional water mitigation and initial restoration of domestic dwellings.

- Approved Document $C$ of the Building regulations

- CLG, (2006), Planning Policy Statement 25: Development and Flood Risk (PPS25), Department of Communities and Local Government, London

- CLG, (2007), Improving the Flood Performance of New Buildings, Department of Communities and Local Government, London

- Environment Agency Flood risk mapping website

- Scottish Environmental Protection Agency Flood risk mapping website

- DEFRA, (2005), Making space for water, March 2005, DEFRA, London

- EA, (2004), Catchment Flood Management Plans: Policy Guidance

- National Flood Forum website and documentation

- CIRIA Designing for exceedance in urban drainage - good practice (C635)

- CIRIA Low-cost options for prevention of flooding from sewers (C506)

- CIRIA Development \& flood risk - guidance for the construction industry (C624)

- CIRIA Infiltration drainage - manual of good practice (R156)

- CIRIA Scope for control of urban runoff, Volume 1 - overview (R123)

- BRE Climate change - impact on building design and construction.

\section{Post-construction}

- CIRIA Standards for the repair of buildings following flooding (C623)

- BRE Repairing flood damage 
Table 4: The key stakeholders that need to make flood hazard mitigation inputs into the preconstruction phase (after Bosher et al. 2007b)

\begin{tabular}{|c|c|c|}
\hline Phase of DCOP & $\begin{array}{c}\text { Formal specified input } \\
\text { required by .. }\end{array}$ & $\begin{array}{c}\text { Formal unspecified input } \\
\text { required by .. }\end{array}$ \\
\hline $\begin{array}{l}\text { Pre-Construction } \\
\text { Stages of this phase include: } \\
\text { - Outline proposals/Outline } \\
\text { conceptual design } \\
\text { - Scheme design/Full } \\
\text { conceptual design } \\
\text { - Detail design/Coordinated } \\
\text { design } \\
\text { - Production information } \\
\text { - Tender documentation } \\
\text { - Tender action }\end{array}$ & $\begin{array}{l}\text { Architects/designers } \\
\text { Engineering consultants } \\
\text { Structural engineers } \\
\text { Specialist contractors } \\
\text { Urban planners/designers } \\
\text { Civil Engineers } \\
\text { Emergency/risk managers } \\
\text { Local authorities } \\
\text { Developers } \\
\text { Contractors } \\
\text { Materials suppliers } \\
\text { Clients } \\
\text { Utilities companies } \\
\text { Quantity surveyors }\end{array}$ & $\begin{array}{l}\text { Emergency services } \\
\text { End users } \\
\text { Government agencies } \\
\text { Insurers }\end{array}$ \\
\hline
\end{tabular}

Note: Formal specified input: Essential structured input that may need to be driven by legislation.

Formal unspecified input: Essential input that may be driven by 'best practice' guidance rather than legislation

\section{Notes}

\footnotetext{
${ }^{1}$ Structural mitigation includes the strengthening of buildings and infrastructure exposed to hazards (via building codes, engineering design and construction practices, etc.).

${ }^{2}$ Non-structural mitigation includes directing new development away from known hazard locations through land use plans and regulations, relocating existing developments to safer areas and maintaining protective features of the natural environment (such as sand dunes, forests and vegetated areas that can absorb and reduce hazard impacts).

${ }^{3}$ The indicative list of hazards in the UK that was provided to the respondents did not include hazards such as earthquakes, volcanoes, tsunamis and meteorites as these (in the present context) were not considered by the authors to be key threats to the UK. In addition fire hazards were omitted from the survey because fire related hazards are already encompassed by existing building and design, and a raft of other, regulations.

${ }^{4}$ It should be noted that the guidance contained within the document is limited to 'new properties in low or residual flood risk areas' (CLG 2007: 8).

${ }^{5}$ For more information about the charrette workshops and how they are being used to stimulate informed decision making on resilience considerations, please refer to Glass et al. 2008.

${ }^{6}$ It is anticipated that the toolkit may consist of a range of tools such as a CD-ROM based software package, guidance manuals and a matrix to signpost decision makers at the most appropriate stages of their projects to key regulations, guidance and best practice literature. It is important to emphasise that it isn't feasible to be too prescriptive about what solutions will be required as these will inevitably be contingent upon the types of built asset and the nature of the hazards that have been identified.
} 